\title{
Changes in concentration of volatile compounds in response to defoliation of Muscat of Alexandria grapevines grown under a traditional farming system
}

\author{
Guillermo A. Pascual ${ }^{1 *}$, Ignacio Serra ${ }^{1}$, Arturo Calderón-Orellana ${ }^{1}$,
}

V. Felipe Laurie ${ }^{2}$, and María Dolores López ${ }^{1}$

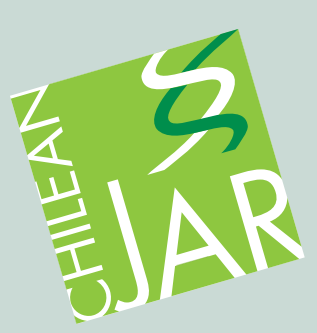

\section{ABSTRACT}

Linalool is a monoterpene, which exhibits floral and spicy aromas as well as a variety of pharmacological effects, including antioxidant, anti-inflammatory, and cardiovascular. Wine flavor is highly dependent on the chemical compounds of berries. The objective of this study was to evaluate the concentration of volatile compounds, especially linalool, in grapes (Vitis vinifera L.) 'Muscat of Alexandria' grown under different cluster light exposure. Four defoliation treatments were applied at veraison, and changed the light environment at the fruit zone. Severe defoliation (T1): leaves were manually removed from the $1^{\text {st }}$ to the $8^{\text {th }}$ node of each shoot, partial defoliation (T2): leaves were manually removed from the $1^{\text {st }}$ to the $4^{\text {th }}$, semi-shaded clusters (T3): un-trimmed vines were covered with an $80 \%$ shade netting; and (T4) control treatment with non-intervention during season 2014-2015. Free terpenes were extracted using headspace solid-phase microextraction (HS-SPME), and the concentration of volatile compounds was determined using gas chromatography coupled to a flame ionization detector (GC-FID). The study was conducted in two different locations of the Itata Valley in Chile. Linalool concentration was more prevalent in treatments with higher cluster exposure. The treatment with the highest defoliation showed a linalool concentration $40 \%$ higher than the control treatment. Higher levels of defoliation in grapevines grown under a traditional farming system result in an increased concentration of volatiles compounds, particularly monoterpenes, where Cerro Verde and Pinihue reached linalool concentrations of 19.1 and $21.7 \mu \mathrm{g} \mathrm{L}^{-1}$, respectively. These results revealed important differences in the behavior of the synthesis of linalool.

Key words: Aroma, grape, monoterpene fraction, radiation, Vitis vinifera, wine.

${ }^{1}$ Universidad de Concepción, Facultad de Agronomía, Av. Vicente Méndez 595, Chillán, Chile.

*Corresponding author (gpascual@udec.cl).

${ }^{2}$ Universidad de Talca, Facultad de Ciencias Agrícolas, Campus Lircay $\mathrm{s} / \mathrm{n}$, Talca, Chile.

Received: 27 April 2017.

Accepted: 6 September 2017.

doi:10.4067/S0718-58392017000400373

\section{INTRODUCTION}

Aroma is one of the most important quality attributes of wine (Guasch, 1999). It consists mainly of volatile compounds that are classified into five groups that can be found in wine: monoterpenes (typical of the so-called 'floral' grapes), norisoprenoids, benzenic aromas, aliphatic aromas, and methoxypyrazines (Williams and Allen, 1996). These volatile compounds are synthesized during the ripening stage (Battilana et al., 2011) and their production depends on several factors, such as light exposure, fruit temperature and crop management (McCarthy, 1986). The ripening of grapes involves many processes, including translocation, accumulation, and metabolism of principal components within the berry. Monoterpenes are biologically synthesized from isopentyl pyrophosphate (IPP) and dimethyl pyrophosphate (DMAPP) (Robinson et al., 2014). These precursors are formed via the cytosolic mevalonic acid (MVA) pathway from three acetyl-CoA molecules (Newman and Chappell, 1999). These components found in grapes that are used in wine production. In many cases, these components are subject to further biological and chemical modifications through the course of vinification and maturation. However, they essentially establish the basis of wine composition (Robinson et al., 2014).

Among the volatile compounds of wine grapes, terpenes have a very important role in the aromatic profile of white varieties such as 'Muscat of Alexandria' (Stevens et al., 1996). These wine compounds have concentrations that range from $\mathrm{ng} \mathrm{L}^{-1}$ to $\mathrm{mg} \mathrm{L}^{-1}$ (Ebeler, 2001) in which linalool, geraniol, nerol, $\alpha$-terpineol, $\beta$-citronellol, hotrienol and limonene often exhibit the highest concentrations in grape berries (Guth, 1997).

Both aroma and taste (i.e., flavor) of wine can be influenced by a wide range of variables, including agricultural management (Robinson et al., 2014), vineyard location, and harvest time. Therefore, fruit quality and yield of wine grapes (Vitis vinifera L.) depend on achieving an adequate balance between fruit load and a properly illuminated leaf area, which constitutes an essential requisite for obtaining a suitable aroma composition (Cañón et al., 2014). The increase in sunlight exposure has been related to the improvement of grape quality, leading to fruit richer in soluble solids, anthocyanins and phenols, and lower titratable acidity and malic acid concentration (Diago et al., 2011). Therefore, the degree of fruit exposure contributes to the production of a variety of chemical compounds may induce different responses in berry aroma composition and fruit quality (González-Barreiro et al., 2014). 
On the other hand, excessive fruit exposure may reduce terpene content of berries (Belancic et al., 1997). Whereas the positive effect of light penetration on fruit quality of 'Muscat' grapes is directly related to the synthesis of volatile compounds (Boss et al., 2014), the negative influence of fruit exposure is probably due to the effect of extremely hot temperatures, which are already being experienced in some regions, vine metabolism may be inhibited leading to reduced metabolite accumulations, which may affect wine aroma, color, and other compounds of enological importance (Mira de Orduña, 2010).

More broadly, the number of days with a specific range of temperatures, solar radiation and relative humidity during grape ripening has been associated with resulting wine quality in several wine regions (Soar et al., 2008). Vineyard microclimatic data, including visible light radiation and canopy temperature were also shown to be good indicators of the final grape quality (Zhang et al., 2015). A particular feature of 'Muscat of Alexandria' in the Itata Valley (Biobío Region, Chile) is the use of the gobelet (or bush vines) training system, which does not have a permanent structure to allow the arrangement of shoots to improve light interception and grape yield. In general, these types of vineyards are characterized by low vegetative growth rates, but dense canopies (Lacoste, 2010). The advantage of this system is that vines are close to the ground, favoring the emission of longwave radiation from the soil to the fruit, which may accelerate ripening in cool climates. In contrast, proximity to the soil in warm climates may be a disadvantage due to the impact of high temperatures on fruit composition (Coomby and Dry, 2006) and berry water content (dehydration). This study analyzes the aroma profile of 'Muscat of Alexandria' berries produced in gobelet-trained grapevines subjected to different defoliation treatments at veraison, with a particular focus on terpenes.

\section{MATERIALS AND METHODS}

\section{Location}

This study was carried out in two commercial gobelettrained vineyards of 'Muscat of Alexandria'. These vineyards were located in two contrasting viticultural areas that represent different edaphoclimatic conditions of the Itata Valley, Biobío Region, Chile. One vineyard was located in Cerro Verde viticultural area (36 $\left.44^{\circ} \mathrm{S}, 72^{\circ} 27^{\prime} \mathrm{W}\right)$, Ránquil and the other was located in Pinihue viticultural area $\left(36^{\circ} 36^{\prime} \mathrm{S} 72^{\circ} 44^{\prime} \mathrm{W}\right)$, Coelemu, near the coast of the Itata Valley. Both vineyards were $25 \mathrm{yr}$ old, and planted with a row and vine spacing of $1.5 \mathrm{~m} \times 1.5 \mathrm{~m}$, respectively. Grapevines were located on a hillside facing northeast, no irrigation was applied and they were trained as bush vines with trunks ranging between 30 and $70 \mathrm{~cm}$ height.

Soil samples were taken from both viticultural areas. The results of their chemical composition are shown in Table 1, both soils are granitic origin, topography of ridges and hills, with viable and complex slope (Stolpe, 2006). Cerro Verde location corresponds to the series San Esteban member
Table 1. Soil chemical composition in both viticultural areas.

\begin{tabular}{|c|c|c|c|c|}
\hline \multirow[b]{2}{*}{ Parameter } & \multicolumn{2}{|c|}{ Cerro Verde } & \multicolumn{2}{|c|}{ Pinihue } \\
\hline & Value & Level & Value & Level \\
\hline $\mathrm{pH}$ in water & 5.46 & Low & 5.86 & Low \\
\hline Organic matter, $\%$ & 0.89 & Low & 2.05 & Low \\
\hline Nitrates $\left(\mathrm{N}-\mathrm{NO}_{3}\right), \mathrm{mg} \mathrm{kg}^{-1}$ & 1.00 & Low & 1.30 & Low \\
\hline Ammonium $\left(\mathrm{N}-\mathrm{NH}_{4}\right), \mathrm{mg} \mathrm{kg}^{-1}$ & 5.30 & Low & 5.40 & Low \\
\hline Available N, mg kg-1 & 6.30 & Low & 6.70 & Low \\
\hline Olsen $\mathrm{P}, \mathrm{mg} \mathrm{kg}^{-1}$ & 3.10 & Low & 5.70 & Low \\
\hline Available $\mathrm{K}$, mg kg-1 & 67.9 & Low & 288.50 & High \\
\hline Interchangeable $\mathrm{K}, \mathrm{cmol}_{\mathrm{c}} \mathrm{kg}^{-1}$ & 0.17 & Low & 0.74 & High \\
\hline Interchangeable $\mathrm{Ca}, \mathrm{cmol}_{\mathrm{c}} \mathrm{kg}^{-1}$ & 3.52 & Low & 2.72 & Low \\
\hline Interchangeable $\mathrm{Mg}, \mathrm{cmol}_{\mathrm{c}} \mathrm{kg}^{-1}$ & 1.43 & High & 0.65 & Medium \\
\hline Interchangeable $\mathrm{Na}, \mathrm{cmol}_{\mathrm{c}} \mathrm{kg}^{-1}$ & 0.09 & Low & 0.04 & Low \\
\hline Sum of bases, $\mathrm{cmol}_{\mathrm{c}} \mathrm{kg}^{-1}$ & 5.21 & Medium & 4.16 & Low \\
\hline $\mathrm{Al}$ interchangeable, $\mathrm{cmol}_{\mathrm{c}} \mathrm{kg}^{-1}$ & 0.99 & High & 0.15 & Medium \\
\hline CICE, $\mathrm{cmol}_{\mathrm{c}} \mathrm{kg}^{-1}$ & 6.20 & Medium & 4.31 & Low \\
\hline Al saturation, $\%$ & 15.98 & High & 3.55 & High \\
\hline $\mathrm{K}$ saturation, $\%$ & 2.81 & Low & 17.16 & High \\
\hline Ca saturation, $\%$ & 56.68 & Low & 63.22 & Low \\
\hline Mg saturation, $\%$ & 23.06 & High & 15.06 & High \\
\hline Available S, \% & 67.90 & High & 21.60 & Medium \\
\hline $\mathrm{Fe}, \mathrm{mg} \mathrm{kg}^{-1}$ & 4.80 & High & 7.80 & High \\
\hline $\mathrm{Mn}, \mathrm{mg} \mathrm{kg}^{-1}$ & 2.40 & Low & 20.40 & Medium \\
\hline $\mathrm{Zn}, \mathrm{mg} \mathrm{kg}^{-1}$ & 0.20 & Low & 0.10 & Low \\
\hline $\mathrm{Cu}, \mathrm{mg} \mathrm{kg}^{-1}$ & 0.20 & Low & 0.90 & High \\
\hline $\mathrm{B}, \mathrm{mg} \mathrm{kg}^{-1}$ & 0.90 & Medium & 3.30 & High \\
\hline
\end{tabular}

of the kaolinitic family, mesic of the ultic Haploxeralfs and Pinihue location corresponds to the series Cauquenes member of the fine family, kaolinitic, iso mesic ultic Palexeralfs (CIREN, 1990).

The type of soil may affect availability of water and nutrients to the plant through its retaining capacity; microclimate through its heat-retaining and light reflecting capacity; and root growth through its penetrability (Jackson and Lombard, 1993).

Weather conditions were also measured during the study and data are summarized in Table 2.

\section{Microclimate conditions}

Air temperature was measured in both viticultural area using two data loggers (TinyTag model TALK2 TK-4023, Gemini Data Loggers Ltd., Chichester, UK). One of the data loggers was placed above plant level to record canopy temperature of the plots. The other data logger was installed at the center of the canopy in T4 to measure air temperature in each viticultural area. Temperature was recorded on an hourly basis from December 2014 to March 2015.

Table 2. Means of relative humidity $(\mathrm{RH})$, temperature, soil temperature at $10 \mathrm{~cm}$ and radiation recorded in Itata Valley, Chile, from December to March 2014-2015.

\begin{tabular}{lcccc}
\hline & RH & Temperature & $\begin{array}{c}\text { Soil } \\
\text { temperature }\end{array}$ & Radiation \\
\hline & $\%$ & & & \\
Dec & 53.0 & 19.4 & 29.5 & $\mathrm{MJ} \mathrm{m}^{-2}$ \\
Jan & 48.1 & 22.6 & 31.1 & 27.9 \\
Feb & 47.4 & 21.7 & 27.5 & 29.7 \\
Mar & 54.3 & 20.3 & 23.1 & 25.1 \\
\hline
\end{tabular}


Values obtained during berry ripening (December 2014 to March 2015) were divided into day (average readings between 08:00 to 18:00 h) and night (average readings between 19:00 to 07:00 h), and separated by temperature intervals. Ranges used for daytime temperatures were $<20$ ${ }^{\circ} \mathrm{C} ; \geq 20{ }^{\circ} \mathrm{C}<25{ }^{\circ} \mathrm{C} ; \geq 25{ }^{\circ} \mathrm{C}<30{ }^{\circ} \mathrm{C} ; \geq 30{ }^{\circ} \mathrm{C}<35{ }^{\circ} \mathrm{C} ; \geq 35$ ${ }^{\circ} \mathrm{C}$, while night intervals corresponded to $\leq 12{ }^{\circ} \mathrm{C} ;>12{ }^{\circ} \mathrm{C} \leq$ $14{ }^{\circ} \mathrm{C} ;>14^{\circ} \mathrm{C} \leq 18{ }^{\circ} \mathrm{C} ;>18^{\circ} \mathrm{C}$.

\section{Defoliation treatments}

Three defoliation treatments were applied at veraison. Severe defoliation (T1): Leaves were manually removed from the $1^{\text {st }}$ to the $8^{\text {th }}$ node of each shoot, until intercepted photosynthetically active radiation (PAR) at the fruit zone reached between $60 \%$ and $80 \%$ of the outside PAR. Partial defoliation (T2): Leaves were manually removed from the $1^{\text {st }}$ to the $4^{\text {th }}$ node of each shoot, until intercepted PAR at the fruit zone reached between $40 \%$ and $60 \%$ of the outside PAR. Semi-shaded clusters (T3): Un-trimmed vines were covered with an $80 \%$ shade netting; and (T4) control treatment with non-intervention during season 2014-2015.

In order to determine the degree of defoliation, the incident light at fruit zone was measured at noon (12:00 to 15:00 h) using a portable quantum sensor (LI-191, LI-COR Bioscience, Lincoln, Nebraska, USA).

The experiment used a completely randomized block design, in which each defoliation treatment was replicated three times in $100 \mathrm{~m}^{2}$ plots. Each block-treatment combination consisted of four representative plants, with two buffer grapevines between each plot.

\section{Light exposure}

In regards to PAR, values were recorded within the canopy at heights of $30 \mathrm{~cm}$ and $15 \mathrm{~cm}$ above ground and at ground level, using a portable Quantum Sensor LI-191SA connected to a data logger LI-1400 (LICOR). Light was recorded three times a day (10:00, 12:00 and 14:00 h), using a methodology adapted (Nan et al., 2014).

Data collection started when clusters had 5\% to $15 \%$ soft berries and were changing color (veraison) and continued until $1 \mathrm{wk}$ before harvest. PAR $\left(\mu \mathrm{mol} \mathrm{m} \mathrm{m}^{-2} \mathrm{~s}^{-1}\right)$ was obtained using five measurements in the control treatment for each viticultural area throughout the season 2014-2015.

\section{Chemistry analysis and reagents}

All clusters from the four plants selected for each treatment were harvested. This was carried out using a ripening level between 21-23 ${ }^{\circ}$ Brix. Harvest dates were 30 March 2015 and 2 April 2015 for Pinihue location and Cerro Verde location, respectively. Two hundred berries were removed from the clusters for each replicate corresponding to the four treatments. Berries were selected from three different positions within the cluster (near the pedicel, at the middle of the cluster, and at the bottom of the cluster). Berries were manually taken from each position using the "Poke and grab" method (Rankine et al., 1962), in which the picker's hand removes berries without seeing the cluster. This method was used in order to minimize the sampling time without compromising the precision to estimate fruit ripeness.

Measurements were made of polar and equatorial diameters of fruits. Weight and volume measurements of the 200 berries were also performed.

The berries were crushed in order to analyze titratable acidity, soluble solids, and volatile compounds. Titratable acidity was measured by titration with $\mathrm{NaOH}$ and was expressed as $\mathrm{g}$ sulfuric acid $\mathrm{L}^{-1}$; soluble solids were analyzed using a digital refractometer (Pocket PAL-1,

Figure 1. Main volatile compounds of Vitis vinifera 'Muscat of Alexandria'.<smiles>C=CC(C)(O)CCC=C(C)C</smiles><smiles>CC(C)=CCCC(C)=CCO</smiles>

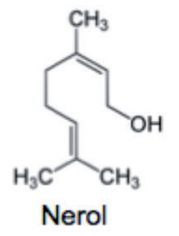

Benzenic compounds<smiles>O=C(O)c1ccccc1</smiles>

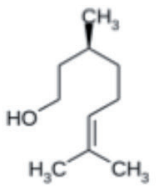

$\beta$-Citronellol

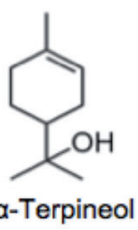

Aliphatic compounds

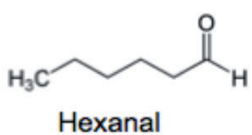

Hexanal

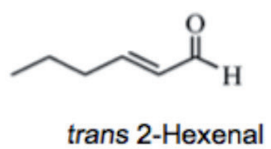

trans 2-Hexenal

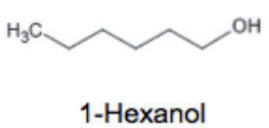


Atago, Japan). Soluble solids were expressed as ${ }^{\circ}$ Brix. For aroma analyses, samples were placed inside hermetic sealed bags, frozen and kept at $-80{ }^{\circ} \mathrm{C}$ until chemical analyses were performed $1 \mathrm{wk}$ after.

Linalool $(\geq 97 \%)$, nerol $(\geq 97 \%)$, geraniol $(98 \%)$, $\beta$-citronellol (95\%), $\alpha$-terpineol (90\%), benzaldehyde (99.5\%), benzyl alcohol (99.8\%), hexanal (98\%), trans-2hexenal $(98 \%), 1$-hexanol $(\geq 98.5 \%)$ were used as standards to identify the main aromas present in grapes as a result of light and temperature conditions (Figure 1). All these reagents were of analytical grade and purchased from Sigma-Aldrich (St. Louis, Missouri, USA).

Concentrations of volatiles compounds were determined according to the headspace solid-phase microextraction (HS-SPME) method reported by Arthur and Pawliszyn (1990). This sample extraction technique was demonstrated to be rapid, simple, and reproducible, with no solvent use, and is suitable for the extraction and concentration of a high number of volatile and semi-volatile compounds from aqueous solutions (Yu et al., 2012). Analyses were conducted using HS-SPME technique followed by gas chromatography coupled with a flame ionization detector (GC-FID), 50/30 $\mu \mathrm{m}$ divinylbenzene/carboxen/ polydimethylsiloxane (DVB/CAR/PDMS) fiber. Sample pre-treatment for volatile analyses was performed as follows: $90 \mathrm{~g}$ juice sample was taken from a macerate that includes skins, pulps, and seeds, mixed with $30 \mathrm{~mL}$ $\mathrm{NaCl}$ solution $(20 \%)$ using a homogenizer (MSH-20A, Wisd, Wertheim, Germany) for $10 \mathrm{~min}$. The mixture was centrifuged (L525R, Cence, Human, China) at $1826 \mathrm{~g}$ for $15 \mathrm{~min}$ and the supernatant was placed in a $15 \mathrm{~mL}$ vial. Then, samples were heated at $40{ }^{\circ} \mathrm{C}$ for $15 \mathrm{~min}$ and SPME fiber was exposed to the headspace during $30 \mathrm{~min}$. Desorption was carried out for $2 \mathrm{~min}$ in the injection port of a gas chromatograph (GC, Varian 3900, Varian Medical Systems, Palo Alto, California, USA) coupled with FID. The chromatographic separation was performed on a CP-Wax $52 \mathrm{CB}$ column under the following conditions: Injector $\mathrm{T}^{\circ} 260{ }^{\circ} \mathrm{C}$; oven $\mathrm{T}^{\circ}$ started at $40{ }^{\circ} \mathrm{C}$ for $1 \mathrm{~min}$, increasing at a rate of $5^{\circ} \mathrm{C} \mathrm{min}{ }^{-1}$ until $200{ }^{\circ} \mathrm{C}$ and then at a rate of $2{ }^{\circ} \mathrm{C} \mathrm{min}^{-1}$ up to $230{ }^{\circ} \mathrm{C}$, which was maintained for 10 min. Hydrogen was used as the gas carrier at a flow rate of $0.8 \mathrm{~mL} \mathrm{~min}^{-1}$. As indicated before, identification of volatile compounds was conducted using pure chemical standards.

\section{Statistics}

All variables studied were statistically analyzed by one-way ANOVA using Infostat software (Infostat Group, Córdoba, Argentina). Mean values were compared using Tukey's test when all the assumptions of the ANOVA were met.

\section{RESULTS AND DISCUSSION}

\section{Temperatures}

In general, Pinihue location exhibited colder nighttime and warmer daytime temperatures above the canopy compared to those recorded in Cerro Verde location (Figure 2).
Temperatures inside the canopy showed important differences between day and night. Had $45 \%$ of days with temperatures above $25^{\circ} \mathrm{C}$ and up to $35^{\circ} \mathrm{C}$ inside the canopy. Similarly, $57.5 \%$ of the days had the same temperatures in Cerro Verde location. In Pinihue location, January temperatures above the canopy level reached $37.5 \%$ for the range $\geq 30{ }^{\circ} \mathrm{C}<35{ }^{\circ} \mathrm{C}$ and $9.7 \%$ for $\geq 35^{\circ} \mathrm{C}$. Cerro Verde location had fewer days with temperatures above $30{ }^{\circ} \mathrm{C}$ compared to Pinihue location. Differences in nighttime temperatures during the season were observed mainly below $12{ }^{\circ} \mathrm{C}$, reaching $27 \%$ in Pinihue location and $12 \%$ in Cerro Verde location. Similarly, Pinihue location reached $23.8 \%$ within the range $<12{ }^{\circ} \mathrm{C}$, while only $8.7 \%$ was recorded in Cerro Verde location.

\section{Light exposure}

The results showed values close to $2000 \mu \mathrm{mol} \mathrm{m} \mathrm{m}^{-2} \mathrm{~s}^{-1}$ during December and January in both viticultural area, and values close to 1500 and $1700 \mu \mathrm{mol} \mathrm{m} \mathrm{m}^{-2} \mathrm{~s}^{-1}$ during February and March in Pinihue and Cerro Verde locations, respectively. These values were recorded at a height of $30 \mathrm{~cm}$ above ground level and the canopy (Figure 3). As expected, incident light inside the plant decreased as measurements were made closer to the ground in both viticultural area. Values obtained at $15 \mathrm{~cm}$ height ranged between 1000 and $800 \mu \mathrm{mol} \mathrm{m} \mathrm{s}^{-2}$, while those obtained at ground level fell below $100 \mu \mathrm{mol} \mathrm{m} \mathrm{m}^{-2} \mathrm{~s}^{-1}$ during the season.

In general, differences in PAR between viticultural areas were small and inconsistent. For instance, the maximum difference in PAR was detected at the soil level between 12 and $14 \mathrm{~h}$, and reached approximately $30 \mu \mathrm{mol} \mathrm{m} \mathrm{m}^{-2} \mathrm{~s}^{-1}$. This difference in PAR between viticultural areas should show little (or no) impact on the concentration of terpenes. Temperature of berries in the field is usually regulated by the radiation flux density absorbed and convection heat loss. Moreover, berry temperature increases linearly with incident radiation (Bergqvist et al., 2001).

It is important to notice that some values showed irregular patterns in both viticultural areas. This may be due to free training systems, in which foliage does not present reinforcement to prevent the movement produced by wind and light variations that may occur. These variables could produce changes in light interception. Incident light values recorded at midday for all levels were higher compared to those recorded at 10:00 and 14:00 h, except at $30 \mathrm{~cm}$ with higher values at 14:00 $\mathrm{h}$ in both viticultural areas.

\section{Fruit maturity}

In general, severe defoliation caused small changes in fruit maturity. However, the effect of the treatments was not the same in both viticultural areas. Whereas in Pinihue location the defoliation treatments exhibited slightly higher Brix and TA than the control, in Cerro Verde location no changes in fruit maturity were observed (Table 3). Higher PAR and daytime temperatures in Pinihue location may explain higher Brix values of severely defoliated vines (Song et al., 2015). However, no known reason can explain why $\mathrm{T} 1$ showed higher TA than the control treatment since changes 
Figure 2. Day and night temperatures recorded during the period December 2014-March 2015 in both viticultural areas: Above canopy at day (i), above canopy at night (ii), within the canopy at day (iii), and within the canopy at night (iv).

(i)

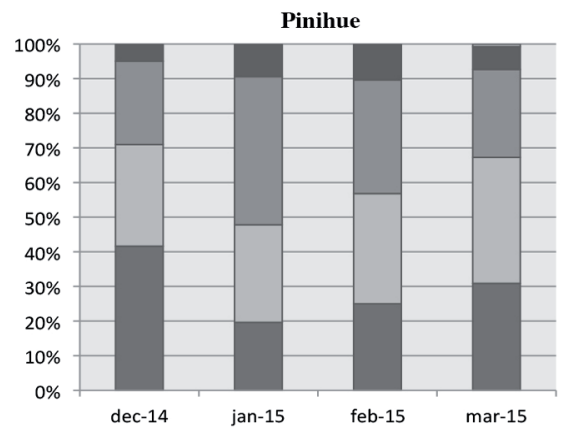

(ii)

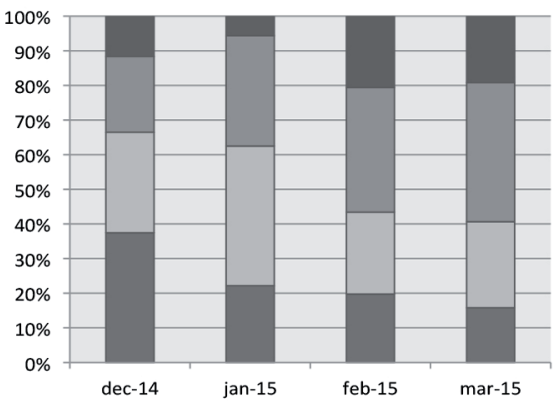

घ $\mathrm{T}>18$

$\square \% \mathrm{~T}>14 \leq 18$

$\square \% \mathrm{~T}>12 \leq 14$

a $\mathrm{T} \leq 12 \mathrm{O}$

(iii)

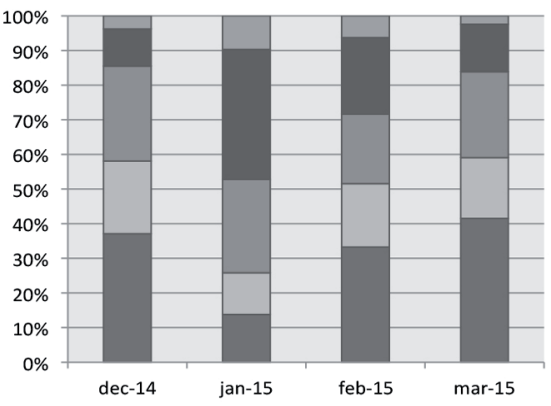

(iv)

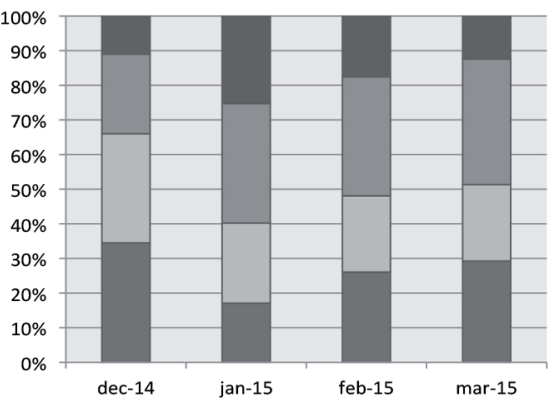

A

$\square \% \mathrm{~T}<20$

a $\mathrm{T}>18$

$\square \% \mathrm{~T}>14 \leq 18$

$\square \% \mathrm{~T}>12 \leq 14$

$\square \% \mathrm{~T} \leq 12$
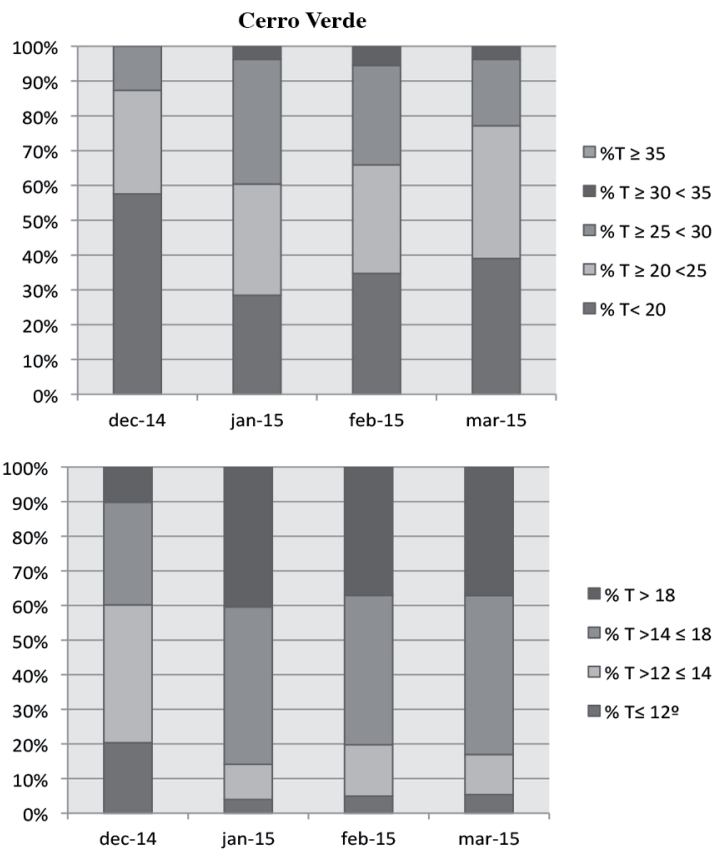

- $\% \mathrm{~T}>18$

$\square \% \mathrm{~T}>14 \leq 18$

$\square \% \mathrm{~T}>12 \leq 14$

- $\%$ T 12 은

$\square \% \mathrm{~T} \geq 35$

$=\% \mathrm{~T} \geq 30<35$

$\square \% \mathrm{~T} \geq 25<30$

$\square \% \mathrm{~T} \geq 20<25$

$\square \% \mathrm{~T}<20$
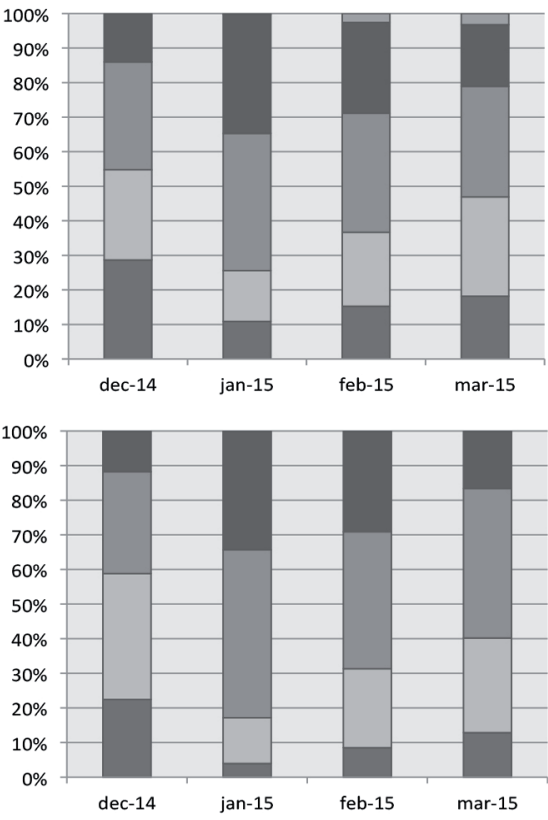

무 $\mathrm{T}>18$

$\square \% \mathrm{~T}>14 \leq 18$

$\square \% \mathrm{~T}>12 \leq 14$

ㅁ $\mathrm{T} \leq 12$ 음

in radiation and temperature are not generally related to increases in TA (Berli et al., 2011).

The $\mathrm{pH}$ values for each treatment are included in Table 3 , nonsignificant differences were found for this parameter, with the exception of Pinihue location, in which T2 exhibited greater $\mathrm{pH}$ than $\mathrm{T} 3$.

Berry weight showed nonsignificant differences among treatments (Table 3 ). In fact, no differences in berry volume, estimated as the volume of an ellipsoid, were found among treatments. As berry weight and volume were not affected by treatments. Therefore, greater concentration of free terpenes in T1 (Table 4) must have been due to greater rates of biosynthesis and/or lower rates of degradation.

Concentration of volatile compounds

The concentration of volatile compounds identified in both viticultural areas through SPME-GC/FID are shown in Figure 4.

Intense defoliation (T1) resulted in higher concentrations of linalool compared to the control treatment in both viticultural areas and being higher in the concentration compared to the rest of the treatments, regardless of differences in climatic conditions and viticultural management. On the other hand, geraniol, nerol and $\alpha$-terpineol, were significantly higher only in Cerro Verde location. These results highlight the importance of canopy management in the profile aroma of 'Muscat 
Figure 3. Photosynthetically active radiation (PAR) for both viticultural areas, (A) Pinihue and (B) Cerro Verde. Measurements above canopy (i), $30 \mathrm{~cm}$ (ii), $15 \mathrm{~cm}$ (iii), and ground level (iv). Measurements were taken between December 2014 and March 2015 at 10:00, 12:00 and 14:00 $h$. Error bars represent standard error of the mean $(n=6)$.

(i)

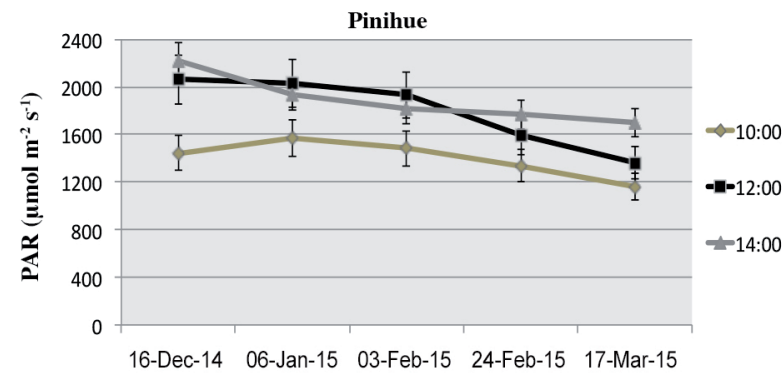

(ii)

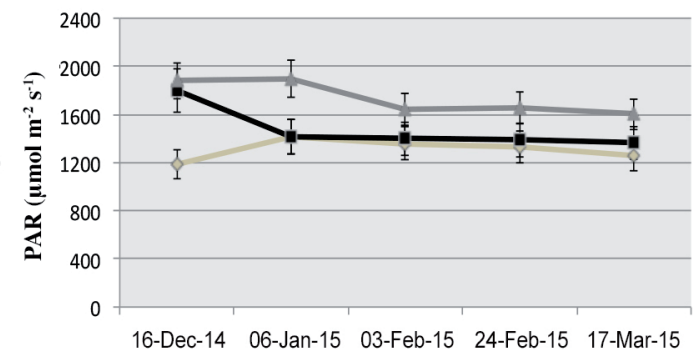

(iii)

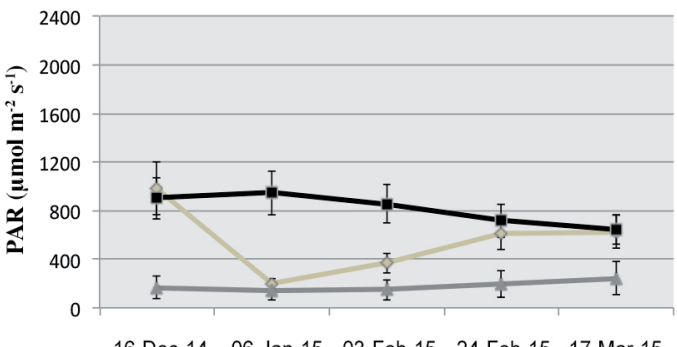

16-Dec-14 06-Jan-15 03-Feb-15 24-Feb-15 17-Mar-15

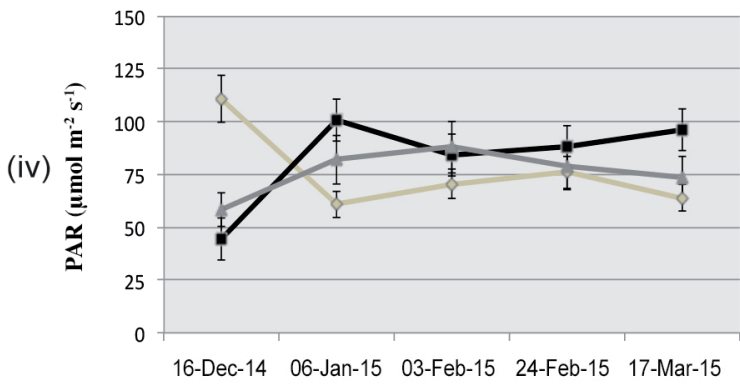

A
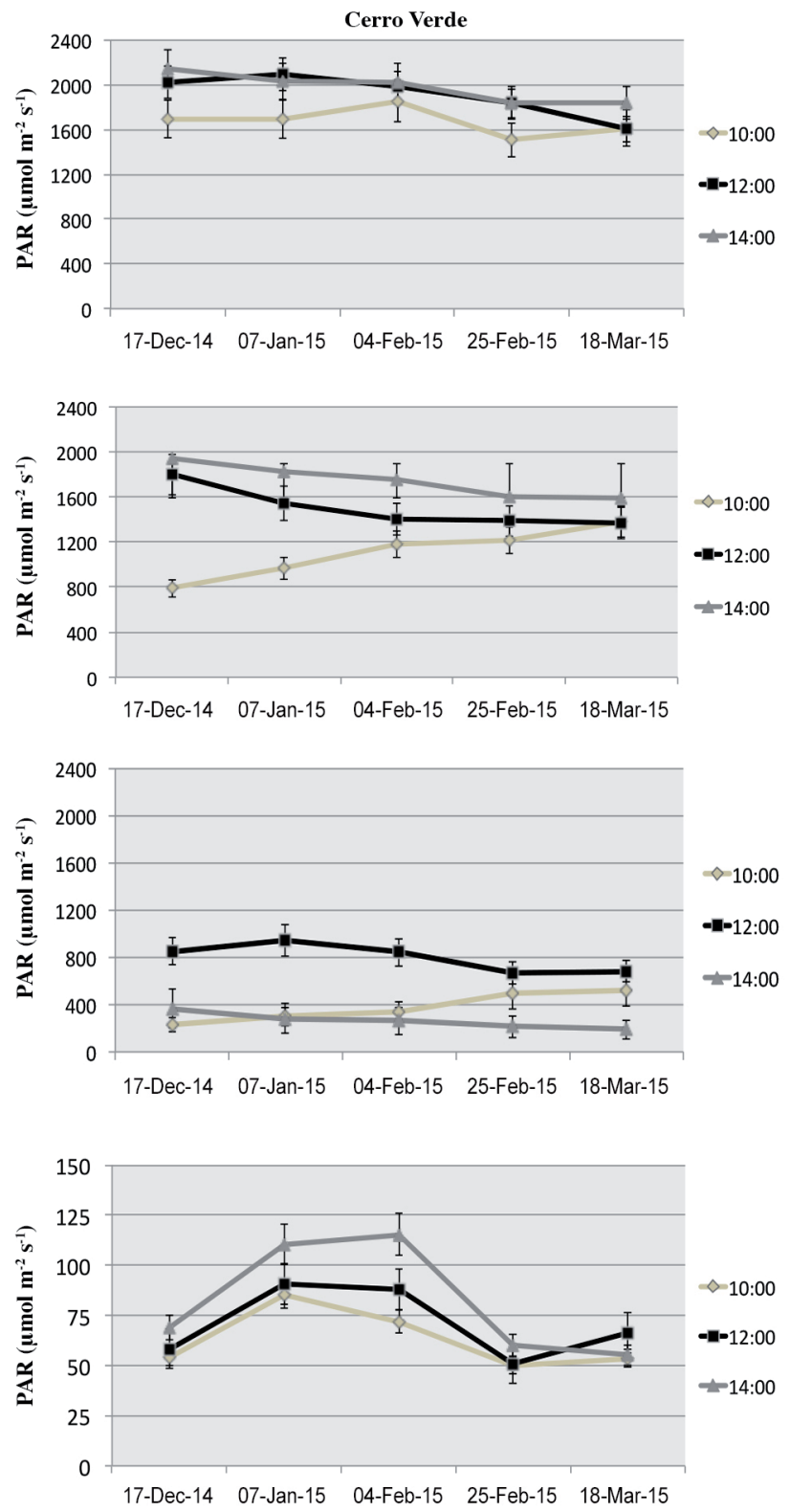

B

of Alexandria', since microclimate conditions seem to be more relevant to determine linalool concentration in berries than differences in mesoclimatic characteristics. Conversely, other important monoterpenes, such as $\alpha$-terpineol, geraniol, and nerol, were more sensitive to mesoclimatic differences and the effect of defoliation was not consistent. The influence of mesoclimatic conditions on the effect of canopy management on monoterpene accumulation has been reported by Skinkis et al. (2010) in 'Gewürztraminer' vines, in which defoliated vines showed no changes in monoterpene concentrations when vineyards were established in warm areas. The higher temperatures recorded within the canopy during the day could indicate

that Pinihue vines location have less leaves than Cerro Verde location.

The degree of openness in the vine canopy may not reflect the amount of intercepted PAR, as this is function of leaf coverage and not leaf density. In the present study, diurnal air temperatures within vines were higher in Pinihue than in Cerro Verde locations. On the other hand, nocturnal temperatures were cooler in Pinihue location. This thermal behavior is typical of more open canopies (less dense), in which empty spaces between leaves allow faster heating and cooling during the day and night, respectively.

Therefore, vines from Pinihue location may be more exposed to the effect of sunlight on berry temperature, 
Table 3. Measurement of ${ }^{\circ}$ Brix, titratable acidity, pH, berry weight and volume in Vitis vinifera 'Moscatel de Alejandria' at harvest in both viticultural areas.

\begin{tabular}{|c|c|c|c|c|c|}
\hline Treatment & ${ }^{\circ}$ Brix & $\begin{array}{c}\text { Titratable } \\
\text { acidity }\end{array}$ & $\mathrm{pH}$ & $\begin{array}{l}\text { Berry } \\
\text { weight }\end{array}$ & Volume \\
\hline & \multicolumn{3}{|c|}{$\mathrm{g} \mathrm{L}^{-1} \mathrm{H}_{2} \mathrm{SO}_{4}$} & $\mathrm{~g}$ & $\mathrm{~cm}^{3}$ \\
\hline & \multicolumn{5}{|c|}{ Pinihue } \\
\hline $\mathrm{T} 1$ & $23.1 \mathrm{a}$ & $3.5 \mathrm{a}$ & $3.75 \mathrm{ab}$ & $3.41 \mathrm{~ns}$ & $29.5 \mathrm{~ns}$ \\
\hline $\mathrm{T} 2$ & $22.6 a b$ & $3.4 \mathrm{a}$ & $3.93 \mathrm{a}$ & 3.62 & 32.3 \\
\hline $\mathrm{T} 3$ & $22.3 b c$ & $3.3 \mathrm{a}$ & $3.63 b$ & 3.39 & 30.4 \\
\hline \multirow[t]{2}{*}{ Control } & $21.7 \mathrm{c}$ & $2.9 \mathrm{c}$ & $3.72 \mathrm{ab}$ & 3.55 & 29.6 \\
\hline & \multicolumn{5}{|c|}{ Cerro Verde } \\
\hline $\mathrm{T} 1$ & $22.6 \mathrm{~ns}$ & $3.1 \mathrm{~ns}$ & $3.81 \mathrm{~ns}$ & $3.39 \mathrm{~ns}$ & $30.1 \mathrm{~ns}$ \\
\hline $\mathrm{T} 2$ & 22.5 & 3.0 & 3.68 & 3.56 & 29.6 \\
\hline T3 & 22.4 & 3.0 & 3.76 & 3.49 & 31.4 \\
\hline Control & 21.2 & 2.7 & 3.65 & 3.55 & 30.4 \\
\hline
\end{tabular}

Values with different letters in same column indicate significant differences $(\mathrm{P}<0.05)$.

All the measurements were taken from a macerate that includes skins, pulp, and seeds.

ns: Nonsignificant.

which could be related to the lack of consistency in terms of the effects observed on $\alpha$-terpineol, geraniol and nerol.

The concentration of volatiles compounds of the present study were considerably lower than those reported in previous study (Belancic et al., 1997). These results may be attributed to differences in viticultural practices that may favor the degradation of volatiles compounds. For instance, the studied vineyard was not irrigated, which means that soil temperature may be as high as $50{ }^{\circ} \mathrm{C}$ (Kerridge et al., 2013). As in the bush-trained system clusters are closer to the soil than in other training systems (i.e., overhead, vertical shoot positioned [VSP, etc.], fruit temperature may reach levels that are detrimental to terpene biosynthesis. Kawoosa et al. (2010) reported that genes involved in terpene synthesis can be down-regulated at temperatures above $25^{\circ} \mathrm{C}$. In this study, daily air temperatures at the fruit zone during veraison (mid-January) were $50 \%$ of the time above $30{ }^{\circ} \mathrm{C}$, which may explain the low concentrations of volatile compounds reported here.

The results of the present study showed that $\alpha$-terpineol was the most abundant monoterpene in berries from both viticultural areas, which is not in agreement with previous studies. Matarese et al. (2014) reported that linalool was the main monoterpene in grape berries, while another study conducted by Del Caro et al. (2012) reported geranic acid concentrations higher than linalool, which is widely regarded as the most abundant terpene in white wines (Kamble et al., 2016).

Severely defoliated vines exhibited higher concentrations of benzyl alcohol than the control treatment in Cerro Verde location, unlike with Pinihue location where control treatment exhibited higher concentrations respect $\mathrm{T} 1$ and T3. Benzyl alcohol is a varietal compound that occurs in berry skins in the free state (Romero, 2008). In general, benzoic compounds accumulate from veraison through to the middle of the ripening stage. The result of aliphatic compounds, in Cerro Verde location hexanal show higher concentration in intense defoliation (T1) compared with control treatment, this compound could be the major contributor to green-vegetal aroma of some nonaromatic cultivars of grape berries (Fan et al., 2010). Thereafter these concentrations progressively decrease (García et al., 2003). This may explain the small concentrations of volatiles studied, mainly in terms of monoterpenes and particularly in Pinihue location. Summer pruning, which is a method of canopy management, can be crucial in obtaining higher concentrations of volatile compounds and, therefore, improving fruit aroma potential. It should be

Table 4. Results of solid-phase microextraction gas chromatography coupled with a flame ionization detector (SPME/GC-FID).

\begin{tabular}{|c|c|c|c|c|c|c|c|c|c|}
\hline \multirow[b]{2}{*}{ Compounds } & & \multicolumn{4}{|c|}{ Cerro verde } & \multicolumn{4}{|c|}{ Pinihue } \\
\hline & & $\mathrm{T} 1$ & $\mathrm{~T} 2$ & $\mathrm{~T} 3$ & $\mathrm{~T} 4$ & $\mathrm{~T} 1$ & $\mathrm{~T} 2$ & $\mathrm{~T} 3$ & $\mathrm{~T} 4$ \\
\hline & \multicolumn{3}{|l|}{ Nr peak } & \multicolumn{2}{|l|}{$\mu g \mathrm{~L}^{-1}$} & \multicolumn{4}{|c|}{$\mu g \mathrm{~L}^{-1}$} \\
\hline Linalool & 1 & $21.7 \mathrm{a}$ & $15.9 \mathrm{~b}$ & $13.8 b$ & $13.2 \mathrm{~b}$ & $19.1 \mathrm{~A}$ & $12.6 \mathrm{~B}$ & $16.0 \mathrm{~B}$ & $12.6 \mathrm{~B}$ \\
\hline Geraniol & 2 & $10.5 \mathrm{a}$ & $4.0 \mathrm{~b}$ & $3.4 \mathrm{~b}$ & $3.3 \mathrm{~b}$ & ND & ND & ND & ND \\
\hline Nerol & 3 & $5.0 \mathrm{a}$ & $2.8 b$ & $2.7 \mathrm{~b}$ & $2.1 \mathrm{~b}$ & $40.5 \mathrm{~ns}$ & ND & ND & ND \\
\hline$\beta$-Citronellol & 4 & $3.1 \mathrm{~ns}$ & ND & $1.9 \mathrm{~ns}$ & $1.9 \mathrm{~ns}$ & ND & ND & ND & ND \\
\hline$\alpha$-Terpineol & 5 & $30.7 \mathrm{a}$ & $27.5 \mathrm{a}$ & $25.2 \mathrm{ab}$ & $20.6 b$ & $41.2 \mathrm{~ns}$ & $50.7 \mathrm{~ns}$ & $32.6 \mathrm{~ns}$ & $49.6 \mathrm{~ns}$ \\
\hline \multicolumn{10}{|l|}{ Benzenic } \\
\hline Benzaldehyde & 6 & $2.2 \mathrm{a}$ & $1.2 \mathrm{a}$ & $1.0 \mathrm{ab}$ & $1.0 \mathrm{~b}$ & $1.8 \mathrm{~ns}$ & $1.4 \mathrm{~ns}$ & $1.3 \mathrm{~ns}$ & $3.2 \mathrm{~ns}$ \\
\hline Benzyl alcohol & 7 & $245.4 \mathrm{a}$ & $195.8 b$ & $194.1 b$ & $186.2 b$ & $105.0 \mathrm{~A}$ & $183.3 \mathrm{BC}$ & $165.3 \mathrm{~B}$ & $232.6 \mathrm{C}$ \\
\hline \multicolumn{10}{|l|}{ Aliphatic } \\
\hline Hexanal & 8 & $54.7 \mathrm{a}$ & $19.1 b$ & $19.1 b$ & $71.7 \mathrm{c}$ & $49.3 \mathrm{AB}$ & $8.8 \mathrm{C}$ & $45.6 \mathrm{~A}$ & $53.1 \mathrm{~B}$ \\
\hline trans-2-hexenal & 9 & $18.0 \mathrm{a}$ & $15.9 \mathrm{~b}$ & $15.5 b$ & $21.4 \mathrm{c}$ & $22.9 \mathrm{~ns}$ & $20.4 \mathrm{~ns}$ & $21.1 \mathrm{~ns}$ & $28.3 \mathrm{~ns}$ \\
\hline 1-Hexanol & 10 & $12.5 \mathrm{~ns}$ & ND & $17.0 \mathrm{~ns}$ & $9.5 \mathrm{~ns}$ & $2.8 \mathrm{~ns}$ & ND & $9.4 \mathrm{~ns}$ & $10.6 \mathrm{~ns}$ \\
\hline
\end{tabular}

ND: Not detected.

Volatiles compounds concentrations are expressed as relative concentration, using a calibration factor of 10 .

Values with different letters within each compound are significantly different at $\mathrm{P}<0.05$, lower-case letters for Cerro Verde location and uppercase letters for Pinihue location.

ns: nonsignificant.

T1: Severe defoliation, intercepted photosynthetically active radiation (PAR) at the fruit zone reached between $60 \%$ and $80 \%$ of the outside PAR.

T2: Partial defoliation, intercepted PAR at the fruit zone reached between $40 \%$ and $60 \%$ of the outside PAR.

T3: Semi-shaded clusters, untrimmed vines were covered with an $80 \%$ shade netting.

T4: Control treatment with no-intervention during season 2014-2015. 
Figure 4. Results of solid-phase microextraction gas chromatography coupled with a flame ionization detector (SPME/GC-FID) for Cerro Verde (i) and Pinihue (ii) locations. [1: linalool; 2: geraniol; 3: nerol; 4: $\beta$-citronellol; 5: $\alpha$-terpineol; 6: benzaldehyde; 7: benzyl alcohol; 8: hexanal; 9: trans-2-hexenal; 10: 1-hexanol]
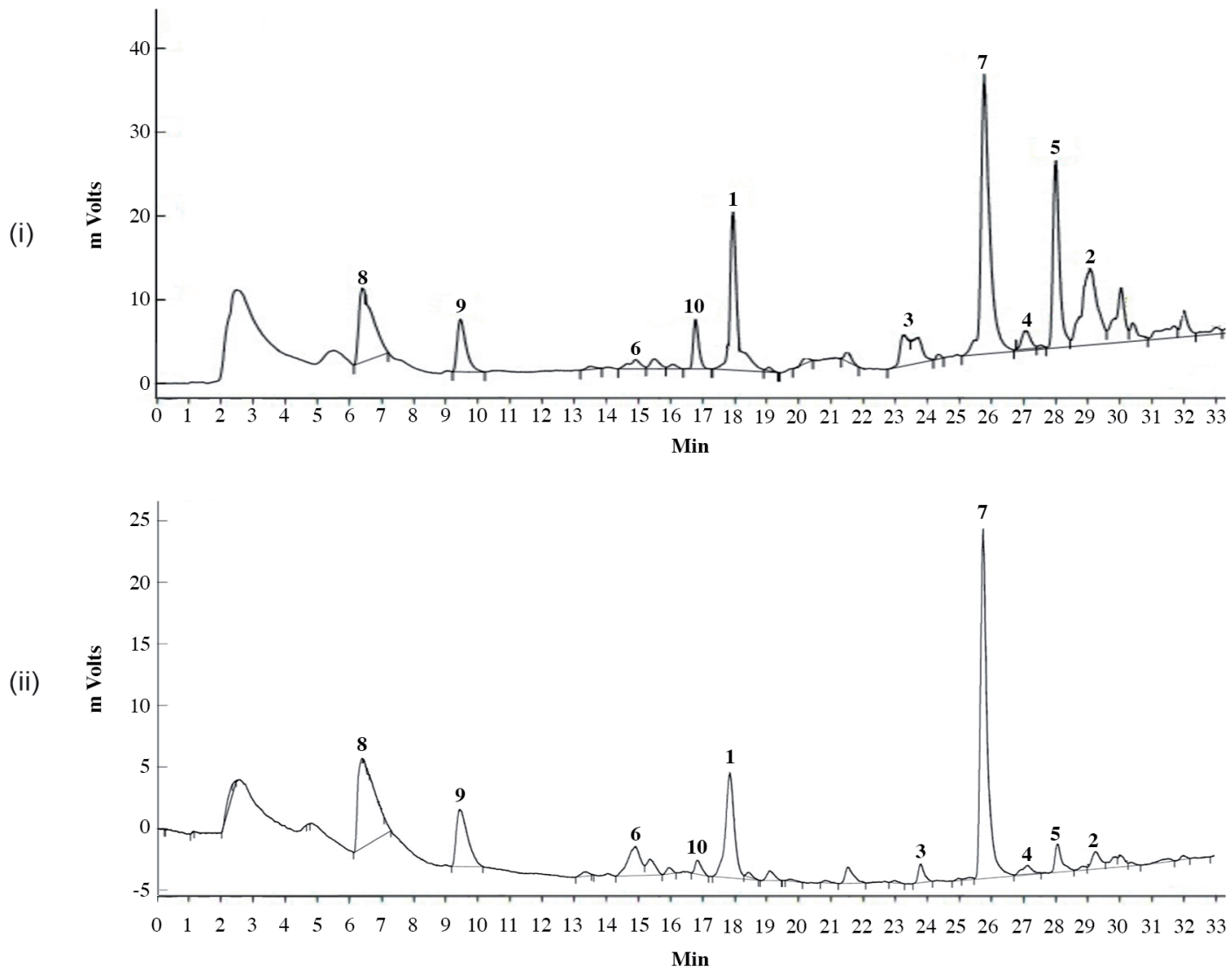

(T1): Leaves were manually removed from the $1^{\text {st }}$ to the $8^{\text {th }}$ node of each shoot, until intercepted PAR at the fruit zone reached between $60 \%$ and $80 \%$ of the outside PAR.

highlighted that linalool contributes to the characteristic and strong aroma of 'Muscat' wines, being the most abundant monoterpene found in white wines (Vilanova et al., 2013). The results obtained from this study can help improve the understanding of the relationship between canopy management and concentration of the main aromatic compounds in berries and wines as well as the beneficial health effects related to moderate wine consumption.

\section{CONCLUSIONS}

Light interception at fruit zone is determined to a large extent by the training system used in vineyards. In the present study, the management of canopy in a gobelet system seems to change the concentration of monoterpenes in the berries due to the differences in sunlight exposure.

In this context, more severe defoliation (60\%-80\% fruit light exposure) of gobelet-trained vines presented high concentrations of volatiles compounds, particularly monoterpenes. Although linalool was not the most important monoterpene found in berries, it was the only monoterpene that showed a consistent response to defoliation. Additionally, the geographic difference between both viticultural areas may have had a significant influence on the accumulation of the volatile compounds. This study highlighted the importance of canopy management to determine the profile aroma of 'Muscat of Alexandria'. These results provide useful information for sustainability of traditional Chilean systems and production of high quality must with beneficial health effects.

\section{REFERENCES}

Arthur, C.L., and Pawliszyn, J. 1990. Solid phase microextraction with thermal desorption using fused silica optical fibers. Analytical Chemistry 62:2145-2148

Battilana, J., Emanuelli, F., Gambino, G., Gribaudo, I., Gasperi, F., and Boss, P.K. 2011. Functional effect of grapevine 1-deoxy-Dxylulose 5-phosphate synthase substitution K284N on Muscat flavour formation. Journal of Experimental Botany 62:5497-5508.

Belancic, A., Agosin, E., Ibacache, A., Bordeu, E., Baumes, R., and Razungles, A. 1997. Influence of sun exposure on the aromatic composition of Chilean Muscat grape cultivars Moscatel de Alejandría and Moscatel rosada. American Journal of Enology and Viticulture 48:181-186.

Bergqvist, J., Dokoozlian, N., and Ebisura, N. 2001. Sunlight exposure and temperature effects on berry growth and composition of Cabernet sauvignon and Grenache in the Central San Joaquin Valley of California. American Journal of Enology and Viticulture 52:1-17. 
Berli, F.J., Fanzone, M.N., Piccoli, P., and Bottini, R. 2011. Solar UV-B and ABA are involved in phenol metabolism of Vitis vinifera $\mathrm{L}$. increasing biosynthesis of berry skin polyphenols. Journal of Agricultural and Food Chemistry 59:4874-4884.

Boss, P.K., Böttcher, C., and Davies, C. 2014. Various influences of harvest date and fruit sugar content on different wine flavor and aroma compounds. American Journal of Enology and Viticulture 65:341-353.

Cañón, P.M., González, A., Alcalde, J., and Bordeu, E. 2014. Red wine phenolic composition: the effects of summer pruning and cluster thinning. Ciencia e Investigación Agraria 41:235-248.

CIREN. 1990. Estudio agroecológico, Itata I. Descripción de suelos, materiales y símbolos. Publicación CIREN No 89 . Centro de Información de Recursos Naturales (CIREN), Santiago, Chile. In Coomby, B.G., and Dry, P.R. 2006. Viticulture. Vol. 2. Practices. Coomby, B.G., and Dry, P.R. (eds.) Winetitles, Adelaide, Australia.

Del Caro, A., Fanara, C., Genovese, A., Moio, L., Piga, A., and Piombino, P. 2012. Free and enzymatically hydrolysed volatile compounds of sweet wines from Malvasia and Muscat grapes (Vitis vinifera L.) grown in Sardinia. South African Journal of Enology and Viticulture 33:115-121.

Diago, M.P., Ayestarán, B., Guadalupe, Z., Garrido, A., and Tardaguila, J. 2011. Phenolic composition of Tempranillo wines following early defoliation of the vines. Journal of the Science of Food and Agriculture 92:925-34.

Ebeler, S.E. 2001. Analytical chemistry: Unlocking the secrets of wine flavor. Food Review International 17:45-64.

Fan, W., Xu, Y., Jiang, W., and Li, J. 2010. Identification and quantification of impact aroma compounds in 4 nonfloral Vitis vinifera varieties grapes. Journal of Food Science 75:S81-8.

García, E., Chacón, J.L., Martínez, J., and Izquierdo, P.M. 2003. Changes in volatile compounds during ripening in grapes of Aireén, Macabeo and Chardonnay white varieties grown in La Mancha region (Spain). Food Science and Technology International 9:33-41.

González-Barreiro, C., Rial-Otero, R., Cancho-Grande, B., and Simal-Gándara, J. 2014. Wine aroma compounds in grapes: A critical review. Critical Reviews in Food Science and Nutrition 55:202-218.

Guasch, J. 1999. El nas electrònic i el control de qualitat dels vins. Enologia avui, 1999. p. 7-18. IV Jornades en Viticultura i Enologia, Vilafranca del Penedès. Universitat Rovira i Virgili, Facultat d'Enologia de Tarragona, Tarragona, España.

Guth, H. 1997. Quantitation and sensory studies of character impact odorants of different white wine varieties. Journal of Agricultural and Food Chemistry 45:3027-3032.

Jackson, D.I., and Lombard, P.B. 1993. Environmental and management practices affecting grape composition and wine quality - a review. American Journal of Enology and Viticulture 44:409-430.

Kamble, N., Banerjee, K., Wagh, S., Pavale, Y., and Bhange, M. 2016. Evaluation of volatile composition of wine grapes (prefermentative aroma) grown under Indian condition by HS-GCMS. Journal of Multidisciplinary Scientific Research 4:19-23.

Kawoosa, T., Singh, H., Kumar, A., Sharma, S.K., Devi, K., Dutt, S., et al. 2010. Light and temperature regulated terpene biosynthesis: Hepatoprotective monoterpene picroside accumulation in Picrorhiza kurrooa. Functional and Integrative Genomics 10:393-404.

Kerridge, B.L., Hornbuckle, J.W., Christen, E.W., and Faulkner, R.D. 2013. Using soil surface temperature to assess soil evaporation in a drip irrigated vineyard. Agricultural Water Management 116:128-141.
Lacoste, P. 2010. Parrales, braceros y cepas de cabeza: El arte de cultivar la viña en Mendoza y San Juan (1561-1869). Historia (Santiago) 43(1):5-40.

Matarese, F., Cuzzola, A., Scalabrelli, G., and D'Onofri, C. 2014. Expression of terpene synthase genes associated with the formation of volatiles in different organs of Vitis vinifera. Phytochemistry 105:12-24.

McCarthy, M.G. 1986. Influence of irrigation, crop thinning and canopy manipulation on composition and aroma of Riesling grapes. MSc Thesis. University of Adelaide, Adelaide, Australia.

Mira de Orduña, R. 2010. Climate change associated effects on grape and wine quality and production. Food Research International 43(7):1844-1855.

Nan, L., Zhao, X., Liu L., Wang H., Li H., and Huang, J. 2014. A comparative ecophysiology of ecolly (Vitis vinifera L.) under the traditional independent long-stem pruning and crawled cordon training. Pakistan Journal of Botany 46(2):489-496.

Newman, J.D., and Chappell, J. 1999. Isopronoid biosynthesis in plant: Carbon partitioning within the cytoplasmatic pathway. Critical Reviews. Biochemistry and Molecular Biology 34:95-106.

Rankine, B.C., Cellier, K.M., and Boehm, E.W. 1962. Studies on grape variability and field sampling. American Journal of Enology and Viticulture 13:58-72.

Robinson, A.L., Boss, P.K., Solomon, P.S., Trengove, R.D., Heymann, H., and Ebeler, S.E. 2014. Origins of grape and wine aroma. Part 1. Chemical components and viticultural impacts. American Journal of Enology and Viticulture 65:1-24.

Romero, I. 2008. Extracción de compuestos fenólicos de la uva al vino. Papel de las enzimas de maceración. PhD tesis. Universidad de Murcia, Departamento de Tecnología de Alimentos, Nutrición y Bromatología, Murcia, España.

Skinkis, P.A., Bordelon, B.P., and Butz, E.M. 2010. Effects of sunlight exposure on berry and wine monoterpenes and sensory characteristics of Traminette. American Journal of Enology and Viticulture 61:147-156.

Soar, C.J., Sadras, V.O., and Petrie, P.R. 2008. Climate drivers of red wine quality in four contrasting Australian wine regions. Australian Journal of Grape and Wine Research 14:78-90.

Song, J., Smart, R., Wang, H., Dambergs, B., Sparrow, A., and Qian, M.C. 2015. Effect of grape bunch sunlight exposure and UV radiation on phenolics and volatile composition of Vitis vinifera L. cv. Pinot noir wine. Food Chemistry 173:424-431.

Stevens, K.L., Bomben, J., Lee, A., and McFadden, W.H. 1996. Volatiles from grapes. Muscat of Alexandria. Journal of Agricultural and Food Chemistry 14:249-252.

Stolpe, N.B. 2006. Descripciones de los principales suelos de la VIII Región de Chile. p. 293-340. Departamento de Suelos y Recursos Naturales, Universidad de Concepción, Chillán, Chile.

Vilanova, M., Escudero, A., Graña, M., and Cacho, J. 2013. Volatile composition and sensory properties of North West Spain white wines. Food Research International 54:562-568.

Williams, P.J., and Allen, M.S. 1996. Modern methods of plant analysis. Vol. 18. Fruit analysis. p. 37-57. Linskens, H.F., and Jackson, J.F. (eds.) Springer, Berlin, Germany.

Yu, Y-J., Lu, Z-M., Yu, N-H., Xu, W., Li, G-Q., Shi, et al. 2012. HS-SPME/GC-MS and chemometrics for volatile composition of Chinese traditional aromatic vinegar in the Zhenjiang region. Journal of the Institute of Brewing 118:133-141.

Zhang, P., Howell, K., Krstic, M., Herderich, M., Barlow, E.W.R., and Fuentes, S. 2015. Environmental factors and seasonality affect the concentration of Rotundone in Vitis vinifera L. cv. Shiraz wine. PLOS ONE 10:e0133137. 